ECOLOGICA, Vol. 28, No 104 (2021), 611-618

https://doi.org/10.18485/ecologica.2021.28.104.17

Originalni naučni rad

UDC: $338.43: 711.3$

\title{
Diverzifikacija ekonomskih aktivnosti kao faktor održivog ruralnog razvoja
}

\section{Diversification of economic activities as a factor of sustainable rural development}

\author{
Katarina Đurić ${ }^{*}$, Veljko Vukoje ${ }^{2}$, Aleksandar Miljatović ${ }^{3}$ \\ 1,2,3Poljoprivredni fakultet, Univerzitet u Novom Sadu, Trg Dositeja Obradovića 8, Novi Sad, Srbija / \\ Faculty of Agriculture, University of Novi Sad, Trg Dositeja Obradovića 8, Novi Sad, Serbia \\ ${ }^{*}$ Autor za prepisku / Corresponding author
}

Rad primljen / Received: 11.09.2021, Rad prihvaćen / Accepted: 01.11.2021.

Sažetak: U cilju usporavanje depopulacije i jačanja socio-ekonomskog položaja ruralnog stanovništva, Evropska unija u svoju politiku ruralnog razvoja uvodi diverzifikaciju ekonomskih aktivnosti, kao jedan od ključnih instrumenata za ostvarivanje održivog razvoja. Diverzifikacija predstavlja mehanizam agrarne politike oličen u povećanju raznolikosti ekonomskih aktivnosti u sektoru ruralne ekonomije. Društveno-ekonomski razvoj ruralnih područja zasniva se na stvaranju uslova u kojima prihodi ruralnih domaćinstava postaju stabilniji nego u slučaju kada se bave isključivo poljoprivredom. Stabilniji prihodi vezuju se za razvoj ekonomskih aktivnosti u sekundarnom i tercijarnom sektoru. U radu su, primenom deskriptivnog, komparativnog i istorijskog metoda, analizirana i prikazana iskustva evropskih zemalja i Republike Srbije u oblasti diverzifikacije ekonomskih aktivnosti u ruralnim područjima. Cilj istraživanja je da se sagledaju svi benefiti koje diverzifikacija ostvaruje u okviru ekonomske, ekološke i socijalne dimenzije ruralnog razvoja. Ključne prednosti diverzifikacije, kao što su pozitivan uticaj na očuvanje prirodnih resursa, stabilniji prihodi ruralnih domaćinstava i poboljšanje demografske strukture ruralnih područja trebalo bi da budu pokretači aktivnosti na primeni iskustava Evropske unije i u našoj zemlji.

Ključne reči: održivi razvoj, ruralni razvoj, divezifikacija, nepoljoprivredne delatnosti.

\begin{abstract}
In order to slow down the depopulation and strengthen the socio-economic position of the rural population, the European Union is introducing diversification of economic activities into its rural development policy, as one of the key instruments for achieving sustainable development. Diversification is a mechanism of agrarian policy embodied in increasing the diversity of economic activities in the rural economy sector. Socio-economic development of rural areas is based on creating conditions in which the incomes of rural households become more stable than in the case when they are engaged exclusively in agriculture. More stable revenues are linked to the development of economic activities in the secondary and tertiary sectors. The paper, using a descriptive, comparative and historical method, analyzes and presents the experiences of European countries in the field of diversification of economic activities in rural areas. The aim of the research is to look at all the benefits that diversification achieves within the economic, environmental and social dimensions of rural development. Key benefits of diversification, such as a positive impact on the conservation of natural resources, more stable incomes of rural households and improving the demographic structure of rural areas should be the drivers of activities to apply the experience of the European Union in our country.
\end{abstract}

Keywords: sustainable development, rural development, diversification, non-agriculture activities.

\footnotetext{
1orcid.org/0000-0003-4587-5855, e-mail: katarina.djuric@polj.uns.ac.rs

2orcid.org/0000-0002-0801-9043, e-mail:vukoje@polj.uns.ac.rs

${ }^{3}$ orcid.org/0000-0002-3978-5832, e-mail: aleksandar.miljatovic@polj.uns.ac.rs
} 


\section{UVOD / INTRODUCTION}

Politika ekonomskog rasta koja ne uzima u obzir mogućnost regeneracije planete uslovila je brojne negativne efekte, kako po životnu sredinu, tako i u socio-ekonomskom smislu. Osim pozitivnih promena, razvoj nauke i tehnologije doveo je i do negativnih promena za čovečanstvo (Dinić i dr., 2021). Podstaknuta činjenicom o nagomilavanju tih negativnih pojava, Svetska komisija za životnu sredinu je daleke 1987. godine usvojila dokument pod nazivom „Naša zejednička budućnost". U ovom dokumentu prvi put je upotrebljen izraz „održivi razvoj“, a definisan je kao razvoj koji zadovoljava trenutne zahteve, ne ograničavajući mogućnosti budućih generacija da ostvare svoje potrebe (Emas, 2015). Opšti cilj održivog razvoja je ostvarivanje dugoročne stabilnosti, što je moguće realizovati objedinjavanjem ekonomskih, ekoloških i socijalnih razvojnih aspekata (Stoddart, 2011).

Koncept održive poljoprivrede nastao je kao odgovor na sve veću ugroženost i degradaciju prirodnih resursa do koje dolazi usled sve intenzivnije proizvodne tehnologije. Pri tome, prema dokumetnu Agenda 21, koji su Ujedinjene Nacije usvojile 1992. godine, održiva poljoprivreda definiše se kao način proizvodnje koji unapređuje kvalitet životne sredine i resurse na kojima se proizvodnja zasniva, zadovoljava čovekove potrebe za hranom, ima ekonomsku isplativost i unapređuje kvalitet života poljoprivrednika i celokupnog društva. Održivi razvoj ruralnih područja obuhvata tri dimenzije: ekonomsku, socijalnu (društvenu) i ekološku. Ekonomska održivost podrazumeva obezbeđivanje ekonomske ravnopravnosti, odnosno jednake koristi za poljoprivrednike kao i za zaposlene u drugim sektorima. Socijalna, odnosno društvena održivost ostvaruje se obezbeđivanjem ravnopravnih uslova razvoja takozvanih osetljivih grupa stanovništva u ruralnim sredinama, kao što su stari, žene, deca, izbeglice. Ekološka dimenzija ruralnog razvoja odnosi se na racionalno gazdovanje prirodnim resursima (Bogdanov, 2015).

Ruralni razvoj je koncept koji, pored politike unapređenja poljoprivrede, uključuje i druge sektorske politike, zatim strukturne i socijalne politike, kao i sve vrste lokalnih inicijativa koje doprinose napretku ruralne zajednice (Isac, 2009). Ruralni razvoj, kao razvojni koncept koji je fokusiran na ekološku, ekonomsku i socijalnu održivost seoskih lokalnih zajednica, usmeren je na redukciju siromaštva, ostvarivanje balansiranog regionalnog razvoja, obezbeđivanje prehrambene sigurnosti, kao i održivo upravljanje prirodnim resursima.

Jedan od primarnih ciljeva politike ruralnog razvoja je redukcija siromaštva. Siromaštvo je kompleksan fenomen koji ima više pojavnih oblika. Klasična definicija siromaštva se bazira na analizi dohotka ili potrošnje, odnosno na finansijskom profilu osobe, domaćinstva ili zemlje (Pantelić, 2017). Osoba je siromašna ako je dohodak kojim raspolaže ispod određene, unapred utvrđene linije siromaštva. Međutim, bez obzira o kom obliku i nivou siromaštva se radi, ono je po pravilu u većoj meri zastupljeno u ruralnim u odnosu na urbana područja. $S$ obzirom da tradicionalni metodi za smanjenje siromaštva nisu dali zadovoljavajuće rezultate, poželjno je razmotriti nove pristupe. Upravo zbog te činjenice apostrofira se uloga politike ruralnog razvoja u procesu unapređenja ekonomskog položaja poljoprivrednih gazdinstava, između ostalog, i na osnovu diverzifikacije ruralne ekonomije.

Ruralno siromaštvo uzrokovano je velikim brojem faktora. Niski i nestabilni prihodi poljoprivrednih gazdinstava, nepovoljna demografska struktura, nedostatak radnih mesta, visoka stopa nezaposlenosti, spor razvoj tercijarnog sektora, nerazvijenost prerađivačkih kapaciteta i ograničena sredstva za investiranje predstavljaju ključne limitirajuće faktore razvoja ruralnih područja. Jedno od rešenja kojim se može uticati na eliminisanje i/ili ublažavanje navedenih ograničenja je diverzifikacija ruralne ekonomije, odnosno uvođenje nepoljoprivrednih aktivnosti. Praksa velikog broja zemalja potvrdila je da razvoj nepoljoprivrednih aktivnosti doprinosi racionalnijoj upotrebi postojećih kapaciteta na poljoprivrednom gazdinstvu, a samim tim deluje stimulativno i na ostvarivanje održivog razvoja ruralnih područja (Thomson, 2019).

Cilj rada je analiza dosadašnjih iskustava vezanih za diverzifikaciju ruralne ekonomije kao instrumenta za redukciju siromaštva i ostvarivanje održivog razvoja poljoprivrednih gazdinstava i ruralnih područja. Akcenat $u$ istraživanju usmeren je na modele diverzfikacije koji su svoju afirmaciju pronašli u zemljama Evropske unije, a pokazali su se kao faktor koji ostvaruje pozitivan uticaj na ekonomsku, ekološku i socijalnu održivost u okviru agrarnog i ruralnog razvoja. Takođe, cilj istraživanja je utvrđivanje ostvarenih dometa diverzifikacije privrednih aktivnosti $\mathrm{u}$ ruralnim područjima $\mathrm{u}$ Republici Srbiji, kao i sistema podrške, koji se kroz mere agrarne poltike usmeravaju ka ostvarivanju većeg stepena diverzfikacije. $U$ radu su korišćene metode istraživanja svojstvene društvenim naukama.

\section{MATERIJALI I METODE RADA / MATHERIALS AND METHODS}

$S$ obzirom da diverzifikacija ruralne ekonomije, pored ekonomske i socijalne, ima izraženu ekološku komponentu, kao i to da je već decenijama u primeni u zemljama Evropske unije, kao jedan od mehanizama u okviru politike ruralnog razvoja, čini se opravdanim istraživanje mogućnosti njene primene 
u Republici Srbiji. Značaj istraživanja posebno potkrepljuje činjenica da je posedovna struktura poljoprivrednih gazdinstava na području naše zemlje nepovoljna, te da se mala gazdinstva koja svoj dohodak zasnivaju isključivo na primarnoj poljoprivrednoj proizvodnji u nezavidnoj ekonomskoj poziciji. Opstanak i razvoj ove grupe poljoprivrednih gazdinstava mogao bi se značajno unaprediti kroz diverzfikovanje njihove privredne aktivnosti.

U skladu sa predmetom i ciljem istraživanja primenjeni su metod analize i sinteze, indukcije i dedukcije, istorijski, deskriptivni metod, kao i metod komparativne analize. Podaci o ostvarenom stepenu diverzifikacije ruralne ekonomije u Republici Srbiji zasnivaju se na publikacijama Republičkog zavoda za statistiku, odnosno Popisa poljoprivrede iz 2012. godine. Iskustva zemalja Evropske unije analizirana su na osnovu naučnih publikacija i studija objavljenih u međunarodnim naučnim časopisima.

\section{REZULTATI I DISKUSIJA / \\ RESULTS AND DISCUSSION}

\subsection{Uloga i značaj diverzifikacije ruralne ekonomije / \\ The role and importance of diversification of the rural economy}

Među brojnim definicijama koje ruralna područja opisuju kao područja suprotna od urbanih, sa manjom gustinom naseljenosti, specifičnim stilom i načinom života, izdvaja se i ona u kojoj se pojam „ruralno“ po pravilu vezuje za poljoprivredu, kao osnovnu privrednu delatnost. Ukoliko se pođe od činjenice da je poljoprivredno zemljište, kao primarni uslov i faktor agrarne proizvodnje, rasprostranjeno upravo u ruralnim sredinama, logično je da najveći deo ruralne populacije svoju egzistenciju zasniva upravo na primarnoj poljoprivrednoj proizvodnji. Visok stepen rizika u proizvodnji, uz nedovoljno stimulativnu finansijsku podršku u okviru mera agrarne politike, dovode mala poljoprivredna gazdinstva u situaciju kada je, zbog nestabilnosti prihoda, njihov ekonomski opstanak pod znakom pitanja. Siromaštvo i nezaposlenost u ruralnim područjima u direktnoj su vezi sa visokim stepenom zavisnosti ovih regiona od poljoprivrede (Ristić, 2013). Pojedini autori ističu da upravo monofunkcionalnost poljoprivrede i orijentisanost ruralnih područja isključivo na primarnu poljoprivrednu proizvodnju doprinose derogiranju nivoa životnog standarda ruralne populacije, što dalje prouzrokuje migracije stanovništva i narušavanje demografske slike sela (Merenkova i dr., 2019). Rešavanje narastajućih problema, pre svega opstanka ruralnih zajednica, zahteva prelazak na diverzifikovani model razvoja, koji bi omogućio optimalnu upotrebu resursa, rast zapošljavanja i prihoda ruralne populacije (Trofimova, 2015). Kako iskustva razvijenih zemalja pokazuju, ostvarivanje ekonomske i demografske održivosti ruralnih područja moguće je samo uz usmeravanje podrške razvoju nepoljoprivrednih ekonomskih aktivnosti (Ristić, 2013).

Poljoprivredna gazdinstva suočavaju se sa novim ekonomskim, ekološkim i socijalnim izazovima. Različitim mehanizmima, kroz mere politike ruralnog razvoja, države nastoje da pruže podršku poljoprivrednom sektoru kako bi se što uspešnije adaptirali na nove uslove. Model diverzifikacije, kao sastavni deo politike ruralnog razvoja, treba da bude usklađen sa specifičnim razvojnim potencijalima određenog regiona, jer jedino na taj način se može pozitivno odraziti na ekonomsku održivost, odnosno rast dohotka poljoprivrednih gazdinstava (Claire i dr., 2020).

Diverzifikacija predstavlja model savremenog ruralnog razvoja oličen u povećanju raznolikosti aktivnosti u sektoru ruralne ekonomije. Društvenoekonomski razvoj ruralnih područja zasniva se na stvaranju uslova u kojima prihodi ruralnih domaćinstava postaju stabilniji nego u slučaju kada se ona bave isključivo poljoprivredom. Stabilniji prihodi vezuju se za razvoj ekonomskih aktivnosti u sekundarnom i tercijarnom sektoru.

Postoje dva osnovna modela diverzifikacije ruralne ekonomije: egzogeni i endogeni model. Egzogeni model diverzifikacije zasniva se na subvencijama za preseljenje firmi iz tercijarnog sektora iz urbanih centara u ruralna područja. Endogeni model diverzifikacije je onaj u kome se akcenat stavlja na podsticanje lokalnih kapaciteta i osnivanje specijalizovanih malih i srednjih preduzeća u oblasti turizma, usluga i agrobiznisa. Dakle, dok se egzogeni model zasniva na inostranim i/ili subvencijama na državnom nivou, endogeni model baziran je na lokalnoj inicijativi (Kurdys-Kujawska i dr., 2018).

\subsection{Modeli diverzifikacije ruralne ekonomije - iskustva zemalja Evropske unije / Models of diversification of rural economy - experiences of European Union countries}

Diverzifikacija ruralne ekonomije uvedena je kao jedna od mera politike ruralnog razvoja u Evropskoj uniji u programskom periodu od 2000. do 2006. godine. Prema regulativi za ruralni razvoj koju je Evropska Komisija usvojila 1999. godine, diverzifikacija je definisana na sledeći način: „razvoj alternativnih aktivnosti, u sekundarnom i tercijarnom sektoru, obezbeđuje mesta za zapošljavanje sa ciljem usporavanja procesa depopulacije i jačanja socioekonomskog položaja ruralnog stanovništva" (EC, 1999). 
Program diverzifikacije ruralne ekonomije bio je usmeren na: (1) razvoj alternativnih modela poljoprivredne proizvodnje, (2) razvoj ruralnog turizma, (3) jačanje aktivnosti zaštite prirodnih resursa i životne sredine, (4) očuvanje kulturne baštine i autentičnog ruralnog ambijenta, (5) osnivanje malih preduzeća u agrobiznisu, naročito u domenu prerade primarnih poljoprivrednih proizvoda (EC, 1999). Za ostvarivanje ovih ciljeva bilo je opredeljeno $10 \%$ od ukupnog agrarnog fonda Evropske unije. U narednim programskim periodima, sredstva za ove namene su se uvećavala.

Za programski period od 2007. do 2013. godine Evropska unija je, kao drugi stub Zajedničke agrarne politike, usvojila nezavisnu politiku ruralnog razvoja u kojoj je, pored rasta konkurentnosti i zaštite životne sredine, diverzifikacija ruralne ekonomije postavljena kao treći ključni cilj (Bailey i dr., 2016). Za potrebe diverzifikacije u ovom programskom periodu izdvojeno je $15 \%$ od budžeta namenjenog ruralnom razvoju.

Pored očuvanja biodiverziteta i racionalnog korišćenja prirodnih resursa, mere politike ruralnog razvoja u narednom programskom periodu bile su usmerene ka ostvarivanju socijalne inkluzije i redukcije siromaštva (Stanczuk-Galwiaczek, 2018). Diverzifikacija ekonomskih aktivnosti koja će rezultirati kreiranjem novih radnih mesta i tako doprineti razvoju ruralnih područja jedan je od najvažnijih mehanizama politike ruralnog razvoja Evropske unije za period od 2014. do 2020. godine (Eretova, Jančak, 2017). Diverzifikacija ruralne ekonomije u periodu od 2014. do 2020. godine podsticana je u okviru drugog stuba Zajedničke agrarne politike i to u vidu start-up programa za nepoljoprivredne delatnosti (EC, 2013). Ovom merom promovisana je diverzifikacija u nepoljoprivredne aktivnosti, pre svega pružanje usluga i osnivanje malih i srednjih preduzeća u ruralnim područjima. Prednost u dobijanju subvencija imali su mladi poljoprivrednici i žene, čime se pozitivno uticalo na njihov socio-ekonomski položaj, a indirektno na društvenu, odnosno demografsku održivost ruralnih područja.
Diverzifikacijom ruralne ekonomije napušta se postojeći, tradicionalni model razvoja poljoprivrede. Monofuncionalna ekonomija ustupa mesto polifunkcionalnoj privrednoj aktivnosti u okviru koje se, pored proizvodnje hrane, ruralno stanovništvo bavi i drugim delatnostima koje su vezane za poljoprivredu i/li se oslanjaju na poljoprivredu (Yoshida i dr., 2019). Na taj način, osim stabilnijih prihoda, stvaraju se mogućnosti za rast konkurentnosti ruralnih područja.

\section{Tabela 1. Nove ekonomske aktivnosti u ruralnim područjima}

Table 1. New economic activities in rural areas

\section{Diverzifikovane privredne aktivnosti}

Proizvodnja organske hrane

Stvaranje lokalnih brendova čija je konkurentnost na tržištu zasnovana na visokom kvalitetu

Razvoj ruralnog turizma

Unapređenje modela za racionalnu upotrebu obnovljivih izvora energije

Izvor / Source: (Yoshida i dr., 2019)

Prateći tendencije ruralnog razvoja u zemljama Evropske unije poslednjih decenija uočava se nekoliko zakonitosti (Patrachanova, 2019). Pre svega, poljoprivreda je i dalje dominantan sektor u ruralnim područjima, ali raste značaj nepoljoprivrednih delatnosti. Novi model zapošljavanja u ruralnim područjima zasniva se na smanjenju zapošljavanja u poljoprivredi i povećanju zapošljavanja u sektoru usluga. Kao posledica toga postoji tendencija smanjivanja razlika u ekonomskoj strukturi između urbanih i ruralnih područja. Istraživanja u pojedinim zemljama Evropske unije pokazuju da su se ruralna područja koja su se opredelila za zapošljavanje stanovništva u sektoru usluga suočila sa rastom broja stanovnika, što predstavlja jednu od ključnih prednosti koju donosi diverzifikacija ruralne ekonomije. Drugim rečima, povratak stanovništva na selo ne mora nužno biti vezan za bavljenje poljoprivredom. Oni koji su se opredelili za život u ruralnim područjima mogu se baviti i nepoljoprivrednim delatnostima (Mitrović i dr., 2020).

Tabela 2. Modeli diverzifikacije ruralne ekonomije u zemljama Evropske unije

Table 2. Models of rural economy diversification in European Union countries

\begin{tabular}{|l|l|}
\hline \multicolumn{2}{|c|}{ Ekonomska diverzifikacija ruralnih područja } \\
\hline (1) Proizvodnja hrane & (6) Absorpcija obnovljivih prirodnih resursa \\
\hline (2) Ponovno otvaranje lokalnih poslova & (7) Proizvodnja bioloških proizvoda \\
\hline (3) Rad na razvoju infrastrukture & (8) Razvoj loklanih bredova \\
\hline (4) Aktivnosti vezane za očuvanje prirodnih resursa & (9) Osnivanje malih i srednjih preduzeća u sektoru usluga \\
\hline (5) Razvoj ruralnog, seoskog i eko-turizma & (10) Proizvodnja sirovina za industriju \\
\hline
\end{tabular}

Izvor / Source: (Patrachanova, 2019) 
Tehnološki napredak i rast produktivnosti $u$ poljoprivrednoj proizvodnji vremenom je doveo do smanjenja potreba za radnom snagom. Jedan od načina da se višak radne snage u ruralnim područjima iz primarnog sektora apsorbuje upravo je diverzifikacija ekonomskih aktivnosti. Istraživanja vezana za dostignuti stepen diverzifikacije ruralne ekonomije u zemljama Evropske unije pokazuju izvesne zakonitosti (Thomson, 2019):

Veći stepen diverzifikacije prisutan je na poljoprivrednim gazdinstvima koja raspolažu većim proizvodnim kapacitetima. Tako je u 2008. godini $20 \%$ gazdinstava koja raspolažu sa više od 100 hektara poljoprivrednog zemljišta bilo diverzifikovano, a u kategoriji malih gazdinstava koja raspolažu sa oko 10 hektara zemljišta taj procenat je bio duplo manji;

Veći stepen diverzifikacije prisutan je na poljoprivrednim gazdinstvima koja su orijentisana na stočarsku proizvodnju u odnosu na gazdinstva na kojima dominira biljna proizvodnja;

Veći stepen diverzifikacije ostvaren je u tzv. periurbanim regionima, odnosno ruralnim područijima koja su locirana u blizini gradova;

Veći stepen diverzifikacije ostvaren je u ruralnim regionima koji raspolažu potencijalima za razvoj turizma.

Jedan od modela diverzifikacije ruralne ekonomije je razvoj eko-turizma. Eko-turizam doprinosi zaštiti prirode i racionalnom korišćenju prirodnih resursa, smanjenju nezaposlenosti i siromaštva (Jovanović i dr., 2019). Jedan od dobrih primera je diverzifikacija na gazdinstvima koja se bave stočarskom proizvodnjom kroz razvoj turizma (Panduru i dr., 2021). Izgradnja ugostitetljskih i smeštajnih kapaciteta, koji bi omogućili turistima boravak na gazdinstvu ili organizovanje letnjih kampova za decu i mlade moglo bi da doprinese ekonomskoj održivosti poljoprivrednih gazdinstava kroz plasiranje njihovih proizvoda. Naime, da bi bio ekonomski održiv, turizam mora biti u funkciji održivog okruženja, bilo kulturološkog, bilo prirodnog (Vujović i dr., 2020). Organizovanje ovog vida turizma mora biti u skladu sa ekološkim principima i očuvanjem životne sredine. Kontrola upravljanja resursima, uz izbegavanje fizičkog, hemijskog i biološkog zagađenja osnovni su preduslovi ovakvog modela diverzifikacije ruralne ekonomije.

$\mathrm{U}$ prilog navedenom govore i iskustva poljoprivrednih gazdinstava u Italiji (Giaccio i dr., 2018) koja se u slučaju diverzifikacije kroz agroturizam pre svega vode principima racionalnog korišćenja i očuvanja prirodnih resusa, kao i očuvanja autentičnog ruralnog ambijenta. Ovakvom stanovištu dopinosi i sistem subvencionisanja u okviru Zajedničke agrarne politike koji odobravanje finansijske podrške uslovljava poštovanjem tzv. ekoloških principa.

Tabela 3. Pozitivni efekti diverzifikacije na održivi ruralni razvoj

Table 3. Positive effects of diversification on sustainable rural development

\begin{tabular}{|l|l|l|}
\hline \multicolumn{1}{|c|}{ Ekološka } & \multicolumn{1}{c|}{ Eimenzije ruralnog razvoja } \\
\hline $\begin{array}{l}\text { Racionalna upotreba } \\
\text { prirodnih resursa }\end{array}$ & $\begin{array}{l}\text { Rast zaposlenosti i rast konkurent- } \\
\text { nosti poljoprivrednih gazdinstava }\end{array}$ & $\begin{array}{l}\text { Unapređenje položaja marginalizova- } \\
\text { nih društvenih grupa (mladi, žene) }\end{array}$ \\
\hline $\begin{array}{l}\text { Očuvanje ruralnog } \\
\text { ambijenta }\end{array}$ & Rast stabilnosti prihoda domaćinstva & $\begin{array}{l}\text { Unapređenje demografske strukture } \\
\text { (starosne i obrazovne) }\end{array}$ \\
\hline $\begin{array}{l}\text { Unapređenje kvaliteta } \\
\text { prirodnih resursa }\end{array}$ & $\begin{array}{l}\text { Racionalnije korišćenje raspoloživih } \\
\text { proizvodnih resursa }\end{array}$ & $\begin{array}{l}\text { Smanjivanje regionalnih razlika u } \\
\text { stepenu razvijenosti ruralnih područja }\end{array}$ \\
\hline
\end{tabular}

Izvor / Source: sistematizacija autora

Osim u sferi ekološke održivosti, u kojoj ostvaruje niz pozitivnih efekata, diverzifikacija ruralne ekonomije ima pozitivne implikacije i na socioekonomsku održivost poljoprivrednih gazdinstava (Salvioni i dr., 2020). Naime, studija, koja je tokom 2018. godine sprovedena u 135 regiona 28 zemalja Evropske unije, a koja je bila zasnovana na FADN bazi podataka, potvrdila je postojanje korelacije između stepena diverzifikovanja nepoljoprivrednih aktivnosti i socio-ekonomskih perfomansi poljoprivrednih gazdinstava. Pri tome, uticaj diverzifikacije na socio-ekonomsku održivost gazdinstava znatno je više izražena u centralnim i severnim u odnosu na južne i jugoistočne regione Unije (Trnkova, 2021).

\subsection{Diverzifikacija ruralne ekonomije u Republici Srbiji / Diversification of rural economy in Republic of Serbia}

Diverzifikacija prihoda na poljoprivrednim gazdinstvima u Republici Srbiji prisutna je u svim regionima. Dodatni izvori prihoda, odnosno druge profitabilne aktivnosti (DPA), razlikuju se među pojedinim regionima. Te razlike su rezultat više faktora, 
kao što su: potrebe i aspiracije članova domaćinstva, tradicija, raspoloživi agrarni resursi, raspoloživost radne snage, razvijenost socijalnog kapitala.

Prema podacima Popisa poljoprivrede, koji je sproveden 2012. godine, od ukupnog broja poljoprivrednih gazdinstava u našoj zemlji $12,4 \%$ su gazdinstva koja su, osim iz poljoprivrede, prihod sticala iz nepoljoprivrednih aktivnosti (Tabela 4). Pri tome, najveći stepen diverzifikacije prisutan je u Šumadiji i Zapadnoj Srbiji. U ovom regionu gazdinstva sa drugim profitabilnim aktivnostima čine $16,7 \%$ od ukupnog broja gazdinstava. Najniži nivo diverzifikacije prisutan je u Vojvodini, gde svega $5,7 \%$ gazdinstava stiče prihode izvan poljoprivrede.

Tabela 4. Diverzifikacija ekonomskih aktivnosti na poljoprivrednim gazdinstvima u Republici Srbiji

Table 4. Diversification of economic activities on agricultural holdings in the Republic of Serbia

\begin{tabular}{|l|c|c|c|}
\hline \multirow{2}{*}{ Region } & \multicolumn{3}{|c|}{ Gazdinstva sa DPA } \\
\cline { 2 - 4 } & Broj & $\begin{array}{c}\text { Učešće u } \\
\text { ukupnom } \\
\text { broju (u \%) }\end{array}$ & $\begin{array}{c}\text { Učešće u } \\
\text { ukupnim } \\
\text { površinama } \\
\text { KPZ (u \%) }\end{array}$ \\
\hline Republika Srbija & 78.301 & 12,4 & 18,1 \\
\hline $\begin{array}{l}\text { Beogradski } \\
\text { region }\end{array}$ & 2.903 & 8,7 & 20,0 \\
\hline $\begin{array}{l}\text { Region } \\
\text { Vojvodine }\end{array}$ & 8.405 & 5,7 & 12,7 \\
\hline $\begin{array}{l}\text { Region Šumadije } \\
\text { i Zapadne Srbije }\end{array}$ & 43.816 & 16,7 & 27,0 \\
\hline $\begin{array}{l}\text { Region Južne i } \\
\text { Istočne Srbije }\end{array}$ & 23.177 & 12,3 & 17,2 \\
\hline
\end{tabular}

Izvor / Source: Bogdanov, Babović (2014)

Od nepoljoprivrednih delatnosti, kojima se diverzifikuje ruralna ekonomija na području Republike Srbije, najzastupljenija je prerada primarnih poljoprivrednih proizvoda. Prema podacima Popisa poljoprivrede (RZS, 2013) najveći broj domaćinstava, preko $50 \%$, usmeren je na preradu mleka. Takođe, visoka (oko 30\%) je zastupljenost prerade voća i povrća, dok je prerada mesa delatnost za koju se opredeljuje manji broj gazdinstava. Jedan od dodatnih izvora prihoda gazdinstava u regionu Vojvodine je rad na osnovu ugovora u poljoprivredi, odnosno pružanje usluga poljoprivrednom mehanizacijom. Ovaj oblik diverzifikacije prisutan je kod $20 \%$ gazdinstava na području AP Vojvodine. Od ostalih nepoljoprivrednih aktivnosti, značajan je udeo obrade drveta i ostalih aktivnosti u šumarstvu. Za razliku od zemalja
Evropske unije, u kojima je ruralni turizam jedan od značajnih izvora prihoda na poljoprivrednim gazdinstvima, u našoj zemlji ovaj tip aktivnosti beleži simbolično učešće u strukturi drugih profitabilnih aktivnosti na gazdinstvu.

U cilju unapređenja diverzifikacije ruralne ekonomije u Republici Srbiji sprovode se mere agrarne politike. Zakon o podsticajima u poljoprivredi i ruralnom razvoju (MPŠV, 2016) u okviru podsticaja za mere ruralnog razvoja predviđa i podršku programima za diverzifikaciju dohotka i unapređenje kvaliteta života u ruralnim područjima. Podsticaji se isplaćuju u vidu naknada minimalno $30 \%$ od ukupnih troškova, odnosno vrednosti investicija. Prema Zakonu o podsticajima, podrška diverzifikaciji ruralne ekonomije realizuje se kroz:

- Investicije za unapređenje i razvoj ruralne infrastrukture;

- Unapređenje ekonomskih aktivnosti na selu kroz podršku nepoljoprivrednim aktivnostima;

- Podršku mladima u ruralnim područjima, $\mathrm{i}$

- Sprovođenje aktivnosti u cilju podizanja konkurentnosti u smislu dodavanja vrednosti kroz preradu, kao i uvođenje i sertifikaciju sistema kvaliteta hrane, organskih proizvoda i proizvoda sa oznakom geografskog porekla na gazidinstvima.

Prema Uredbi o raspodeli podsticaja u poljoprivredi i ruralnom razvoju u 2021. godini predviđena su budžetska sredstva namenjena podsticanju diverzifikacije ruralne ekonomije na poljoprivrednim gazdinstvima u Republici Srbiji. Za podsticaj diverzifikaje ruralne ekonomije i unapređenje kvaliteta života u ruralnim područjima izdvojeno je 275 miliona dinara (MPŠV, 2020).

Najveći deo sredstava iz ove mere politike ruralnog razvoja, u iznosu od 200.000 .000 dinara (72\%) usmeren je na unapređenje ruralne infrastrukture $u$ cilju poboljšanja uslova i kvaliteta života. Za diverzifikaciju ruralne ekonomije opredeljeno je ukupno 75.000 .000 dinara, od čega 50.000 .000 dinara (18\%) predstavlja podršku razvoju nepoljoprivrednih aktivnosti, a 25.000 .000 dinara (10\%) raspoređeno je za Sprovođenje aktivnosti u cilju podizanja konkurentnosti u smislu dodavanja vrednosti kroz preradu, kao i uvođenje i sertifikaciju sistema kvaliteta hrane, organskih proizvoda i proizvoda sa oznakom geografskog porekla na gazdinstvima. 
Tabela 5. Budžetska podrška diverzifikaciji ruralne ekonomije u Republici Srbiji u 2021. godini Table 5. Budget support for the diversification of the rural economy in the Republic of Serbia in 2021

\begin{tabular}{|l|c|c|}
\hline \multicolumn{1}{|c|}{ Vrsta podsticaja } & Iznos & Učešće (u \%) \\
\hline $\begin{array}{l}\text { Podsticaji za diverzifikacju i unapređenje kvaliteta života u } \\
\text { ruralnim područjima }\end{array}$ & 275.000 .000 & 100 \\
\hline Podsticaji za unapređenje nepoljoprivrednih aktivnosti & 50.000 .000 & 18 \\
\hline $\begin{array}{l}\text { Podsticaji za podizanja konkurentnosti u smislu dodavanja } \\
\text { vrednosti kroz preradu, kao i uvođenje i sertifikaciju sistema } \\
\text { kvaliteta hrane, organskih proizvoda i proizvoda sa oznakom } \\
\text { geografskog porekla na gazdinstvima }\end{array}$ & 25.000 .000 & 10 \\
\hline Investicije za unapređenje i razvoj ruralne infrastrukture & 200.000 .000 & 72 \\
\hline
\end{tabular}

Izvor / Source: proračun autora na bazi (MPŠV, 2020)

\section{ZAKLJUČAK / CONCLUSION}

Analiza iskustava zemalja Evropske unije pokazuje da diverzifikacija ekonomskih aktivnosti utiče pozitivno na ostvarivanje održivog razvoja ruralnih područja i to u sve tri razvojne dimenzije. Uticaj na ekonomsku održivost ostvaruje se na osnovu obavljanja delatnosti koje se organizuju u okviru poljoprivrednih gazdinstava, a predstavljaju svojevrsnu nadogradnju primarne poljoprivredne proizvodnje. To se, pre svega, odnosi na preradu primarnih poljoprivrednih proizvoda u okviru manjih prerađivačkih pogona. Takođe, plasman prehrambenih proizvoda u okviru sektora usluga, odnosno ruralnog turizma, može značajno doprineti stabilnosti dohotka poljoprivrednih gazdinstava, a samim tim i ekonomski održivom razvoju ruralnih područja.

Uticaj diverzifikacije privrednih aktivnosti na ekološku održivost ruralnog razvoja i očuvanje prirodnih resursa ogleda se u organizovanju organske poljoprivredne proizvodnje, koja se bazira na principima održivog razvoja. Pored organske poljoprivredne proizvodnje, eko-turizam predstavlja delatnost koja, pored ekonomskih, donosi i niz ekoloških benefita ruralnim sredinama.

Najzad, socijalna, a pre svega, demografska održivost ruralnih područja, može u velikoj meri da se bazira na mogućnostima koje pruža diverzifikacija privrednih aktivnosti. Naime, iskustva potvrđuju da razvoj tercijarnog sektora, kako u endogenom, tako i u okviru egzogenog modela diverzifikacije, utiču na rast zaposlenosti, a samim tim i priliv mlade, radno-aktivne populacije u ruralna područja. $\mathrm{Na}$ ovaj način, kroz ekonomske podsticaje, mladi ljudi se mogu motivisati za život u ruralnim područjima, čime se doprinosi poboljšavanju demografske strukture, a samim tim i socijalne održivosti.

Na području Republike Srbije najveći stepen diverzifikacije privrednih aktivnosti ostvaren je u ruralnim područjima Šumadije i Zapadne Srbije, a najzastupljenija nepoljoprivredna delatnost je prerada mleka. Budžetska podrška diverzifikovanju ruralne ekonomije u našoj zemlji realizuje se, po ugledu na model koji primenjuje Evropska unija, u okviru mera politike ruralnog razvoja. Najveći deo podrške usmeren je na unapređenje kvaliteta života u ruralnim područjima kroz razvoj infrastrukure. Takođe, iz budžeta su opredeljena i sredstva namenjena podsticanju nepoljoprivrednih aktivnosti. Iskustva zemalja Evropske unije, kao i brojne prednosti koje diverzifikacija prihoda na poljoprivrednim gazdinstvima obezbeđuje, trebalo bi da posluže kao smernice kreatorima agrarne i politike ruralnog razvoja u Republici Srbiji. Kroz implementaciju sličnih modela podrške mogao bi biti ostvaren veći stepen diverzifikacije, a samim tim bi se uticalo na ekološku, ekonomsku i društvenu održivost ruralnih područja naše zemlje.

\section{Zahvalnica / Acknowledgements}

Sredstva za realizaciju istraživanja obezbeđena su od strane Pokrajinskog sekretarijata za visoko obrazovanje i naučnoistraživačku delatnost AP Vojvodine u okviru projekta „Ekonomska održivost poljoprivrednih gazdinstava AP Vojvodine.

\section{LITERATURA / REFERENCES}

[1] Bailey, A., Lang, T., Schoen, V. (2016). Does the CAP still fit? UK: Food Research Collaboration.

[2] Bogdanov, N. (2015). Ruralni razvoj i ruralna politika, Poljoprivredni fakultet, Beograd

[3] Bogdanov, N., Babović, M. (2014). Radna snaga $i$ aktivnosti poljoprivrednih gazdinstava, Popis poljoprivrede 2012, Republički zavod za statistiku, Beograd.

[4] Claire, J., Ashfield, A., Adenuga, A.H., Mullan, C. (2021). Farm diversitication: drivers, barriers and future growth potential, Euro Choices, 20(2), 7075. http://doi.org/10.1111/1746-692X.12295

[5] Dinić, J., Bukovala, J., Ivannikov, N. (2021). Ekološka politika Evropske unije, Ecologica, 28 (101), 16-21. 
[6] Emas, R. (2015). The Concept of Sustainable Development: Definition and Definig Principles, Brief for Global Sustainable Development Report 2015, United Nations

[7] Eretova, V., Jančak, V. (2017). The past, present and future of diversification of agricultural holdings in Czechia, AUC Geographica, 52(1), 27-37.

[8] European Commission (EC, 1999): EU Regulation No. 1257/1999, Regulation on support for rural development from the EAGGF

[9] European Commission (EC, 2013). EU Regulation No. $1305 / 2013$ on support for rural development by the EAFRD and repealing Council Regulation (EC) No. 1698/2005

[10] Giaccio, V., Mastronardi, L., Marino, D., Giannelli, A., Scardera, A. (2018). Do Rural Policies Impact on Tourism Development in Italy? A Case Study of Agrotourism, Sustainability, 10(8), 2938. doi:10.3390/su10082983.

[11] Isac, N. (2009). Dimension of rural development, Lucrari Stiintifice, Seria I, Management Agricol 11(1).

[12] Jovanović, L., Živković, D., Janković, M., Šiljak, V., Toškić, D. (2019). Significance of sustainable eco-tourism for Serbia`s economic development, Zbornik radova - Geografski fakultet Univerziteta u Beogradu, 67(2), 53-67.

[13] Kurdys-Kujawska, A., Zawadzka, D., SompolskaRzechula, A. (2018). The probability of farms diversification - on the example of Central Pomerania in Poland, Bulgarian Journal of Agricultural Science (Agricultural Academy), 24(2), 171-179.

[14] Merenkova, J., Agibalov, A., Lubkov, V. (2019). Resources for the transition of rural areas to a diversified model, IOP Conf. Series: Earth and Environmental Science 274(1), 012020, doi:10.1088/1755-1315/274/1/012020

[15] Mitrović, S., Mitrović, A., Mitrović, Lj. (2021). Zadrugarstvo kao nova paradigma održivog razvoja ruralnih područja u Srbiji, Ecologica, 28(101), 8290.

[16] MPŠV (2016). Zakon o podsticajima u poljoprivredi i ruralnom razvoju Republike Srbije, Službeni glasnik RS, br. 10/2013, 142/2014, 103/2015, 101/2016

[17] MPŠV (2020). Uredba o raspodeli podsticaja u poljoprivredi i ruralnom razvoju u 2021. godini, Službeni glasnik RS, br. 159/2020

[18] Panduru, E.B., Huzau, G., Vaduva, L., Petroman, I. (2021). The role of the diversification of farm tourism activities in the sustainable development of areas near animal farms, Quaestus multidisciplinary research journal, 18, 330-337.

[19] Pantelić, A. (2017). Suzbijanje siromaštva u zemljama u razvoju, Institut za međunarodnu politiku i privredu, Beograd.

[20] Patrachanova, E. (2019). Metodological aspects of the economic diversification of rural areas and it's impact on settlements, Environmental Legislation, Multilateral Relations and Funding Opportunities, paper presented at 19th International Multidisciplinary Scientific Geo Conference SGEM 2019

[21] Ristić, L. (2013). Strategijsko upravljanje održivim ruralnim razvojem u Republici Srbiji, Ekonomski horizonti, 15(3), 229-243.

[22] RZS (2013). Popis poljoprivrede 2012 - Poljoprivreda u Republici Srbiji, Republički zavod za statistiku, Beograd.

[23] Salvioni, C., Henke, R., Vanni, F. (2020). The Impact of Non-Agricultural Diversification on Financial Performance: Evidence from Family Farms in Italy, Sustainability, 12(2), 486, http://doi.org/10.3390/su12020486

[24] Stanczuk-Galwiaczek, M. (2018). Main directions in the EU member states rural development policies: similarities and dissimilarities, Proceeding of the 2018 International Conference „Economic Sccience for rural development", No 47, Jeglava, LLU ESAF 9,11 May 2018, pp. 322-331.

[25] Stoddart, H. (2011). A pocket guide to sustainable development governance, Stakeholder Forum.

[26] Thomson, K.J. (2019). Rural Diversification and Job Creation in the EU, Rural Policies and Employment, pp. 287-300. https://doi.org/10.1142/9781786347091_0018

[27] Trnkova, G. (2021). The Economic and Social Importance of Farm Diversification towards Nonagricultural Actitivites in EU, Hradec Economic Days, doi: 10.36689/uhk/hed/2021-01-081

[28] Trofimova, V.I. (2015). Diversification of the rural economy as a factor in the development of rural territories, Regional Agrosystems: Economic and Sociology, 2(2), pp. 22 (in Russian).

[29] Vujović, S., Premović, J., Arsić, Lj. (2020). Ekološki aspekti materijalne osnove ruralnog turizma, Ecologica, 27(97), 65-69.

[30] Yoshida, S., Yogi, H., Garrod, G. (2020). Determinants of farm diversification: entrepreneurship, marketing capability and family management, Jour. of Small Business \& Entrepreneurship, 32(6), 607633. doi:10.1080/08276331.2019.1607676 